\title{
Gorontalo
}

\author{
Journal of Government and Political Studies \\ Volume 3 - NO. 1 - April 2020 \\ P-ISSN: 2614-2120 E-ISSN: 2614-2104
}

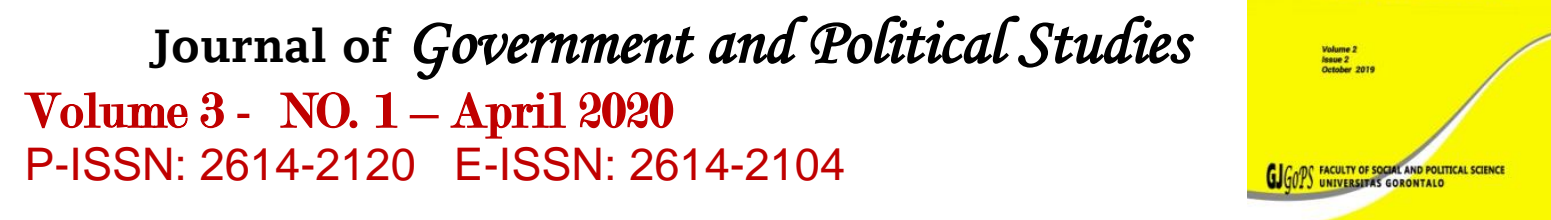

\section{Prevention of Early Marriage in Reducing the Level of Violence Against Women in Gorontalo Regency}

\author{
Aprilia Umar \\ Dewi Walahe \\ Public Administration, Gorontalo University \\ Jalan Ahmad A. Wahab No. 247, Limboto, Gorontalo Regency \\ apriliaumar09@gmail.com \\ dewi.walahe31@gmail.com
}

Received: April 13, 2020; Revised: April 21, 2020

Accepted: April 21, 2020

\begin{abstract}
Data from the Gorontalo Regional Police on cases of violence against women in 2015 were 212 . While the number of violence against children was even more worrying, namely 423 cases, consisting of 232 sexual crimes against children, 181 physical violence and 41 cases of psychological violence. The purpose of this study was to determine efforts to prevent early marriage that have been carried out by the Office of Women's Empowerment and Child Protection in Gorontalo District against female violence and to determine the effect of early marriage prevention on the level of violence on women. The location of this research is the Women's Empowerment and Child Protection Agency. This research uses descriptive qualitative research methods. The results of this study are the efforts made by the Women's Empowerment and Child Protection Agency to prevent early marriage in reducing the level of violence in women, namely through an integrated service center for women and children empowerment, the Task Force Team for Violence against Women and Children, Community-Based Integrated Protection, Socialization, Assistance and Use the Puspaga mobile application.
\end{abstract}

Keywords: prevention; early-age marriage; female violence

\section{INTRODUCTION}

Marriage is binding promises between men and women who love each other which is then validated by religion. Early marriage is a marriage carried out by two people with the intention of formalizing the relationship but the age is not sufficient. So, a marriage is said to be an early marriage if of the two or one of the couples under the age of 20 years. The reason someone does early marriage is because of the desire to immediately get additional family members and lack of knowledge about the effects of marriage at a young age. (Musfiroh, 2016. Journal. Early Marriage and Child Protection Efforts in Indonesia).

Based on the results of the Riskesdas survey (2010) cases of early marriage in Indonesia are still very high, namely women aged 10-14 years reaching more than 22,000 cases or as much as $0.2 \%$ while for women aged 15-19 years at 12.8 percent (BKKBN , 2012. Journal of Early Marriage in Several Provinces in Indonesia: Root Problems and Roles of Institutions in the Regions.). With these 
data, according to Mariyatul (2014. Journal of Factors Affecting Young Women's Marriage). Indonesia became one of the countries with the 37th largest number of marriages out of a total of 158 countries. The highest cases of early marriage actually tend to occur in rural areas. This is due to the fact that people who live in rural areas are still very low in knowledge about the dangers of having a marriage at a young age (BPS, 2016 child marriage marriage book in Indonesia).

In 2013 the number of women aged 20-24 years who were married under the age of 16 was only a small amount, but from the age of 16 to the age of 18 , the number was increasing. The increase in marriages over the age of 16 proves that marriage at the age of 16 and 17 is still rife in Indonesia. A person who is married at the age of 16 is considered legal according to Law No. 1 of 1974 concerning marriage in article 7 paragraph 1 which states that marriage is only permitted if the male has reached the age of 19 (nineteen) years and the woman has reached the age of 16 (sixteen) years. However, Article 6 states that marriages before the age of 21 must obtain parental consent. From this it is clear that the role of parents is very large in the decisions of their marriage, including marriages that are carried out at a young age. Parents are key in efforts to reduce the prevalence of child age marriages so any effort to reduce the prevalence of child age marriages must include education of parents. (BPS. 2016 child marriage book in Indonesia).

Women in Gorontalo Province generally married for the first time at the age of 19-24 (> 45\%). However, the proportion of women who marry at the age of 1618 is also still relatively high (around 30\%) (BKKBN Gorontalo. 2013 artkel. Fertility and Family Planning Trends). In Gorontalo District alone there are around $27.8 \%$ who get married at the age of 15-19 (SUSENAS, 2015).

Violence against women or wives is one of the factors caused by early marriage, this is because the thinking patterns are not mature enough from young couples. Marriage of minors requires serious commitment from the government so that women and men who want to marry underage think twice before doing so. In addition to the serious commitment required by the government, it is also hoped that it will be increasingly active in promoting the law on underage marriages and their sanctions and also explaining the risk of underage marriage to the public. The efforts made by the government are expected to make the public understand and realize that getting married at a young age is something that should be avoided (Hertika et al., 2017. Journal of Early Marriage with the Risk of Violence by Mothers to Preschool-aged Children in Sumbersari Village, Subdistrict Sumbersari, Regency of Jember).

Prevention of marriage at an early age will be maximized if the community wants and participates to prevent underage marriages in their immediate environment. Good cooperation between the community and the government is one of the most effective moves for the time being to prevent early child marriages so that there will be no more victims of early marriage and Indonesia will be an optimistic country to organize the future of children in the the future. (Alfiyah, 2010. Book of Causes of Early Marriage). Violence against women is a matter of concern so public organizations need to overcome it. The emergence of several cases such as sexual harassment of women, moral damage to a woman, rape, crime and persecution. One area with increasing levels of violence against women is Gorontalo District (Febrianto, 2016. Articles on Violence against Children and Women in Gorontalo Are Very Concerning). 
Data from the Gorontalo Regional Police on cases of violence against women in 2015 were 212 . While the number of violence against children was even more worrying, namely 423 cases, consisting of 232 sexual crimes against children, 181 physical violence and 41 cases of psychological violence. Based on these problems, a study was conducted on efforts to prevent early marriages in order to reduce the level of violence in women at the Office of Women's Empowerment and Child Protection in Gorontalo District.

Early marriage is a marriage that takes place before the bride and groom are 18 years old. According to (BKKBN. 2012. Journal of Early Marriage in Several Provinces in Indonesia: Root Problems and Institutional Roles in Regions) in general, early marriage has a general definition, early marriage can be said to be arranged by both parties regardless of the physical and psychological condition of a woman when they have a child.

The cause of early marriage according to the Population and Family Planning Agency (BKKBN) is the existence of norms that apply in communities that have social and economic relations between generations. This is what then spurs "coercion" in marriages or arranged marriages conducted by parents with the reason to reduce the burden and responsibilities in the family, although this is not necessarily proven, because basically women who are forced to marry often experience violence due to differences in understanding with her husband. (BKKBN, 2012. Book. Early Marriage in Several Provinces in Indonesia: Root of the Problem and Institutional Role in the Regions). Getting married under the age of 20 has quite an alarming risk. Mentally, women who are married at the age of under 20 years are actually not ready to face the changes that occur during pregnancy, are not ready to deal with household problems and are not ready to carry out the role of a mother, according to (Qibtiyah. 2014. Journal. Influencing Factors Young Women's Marriage). In this study, researchers found there are various factors that cause young marriages or early marriages, these factors are, family factors namely the role of parents in determining the marriage of their children and individual factors that originate from within themselves, as well as community factors environment originating from the environment such as customs and norms that apply in society.

\section{RESEARCH METHOD}

The method used in this research is a qualitative approach. To obtain the desired data, survey methods will be used to obtain valid data, especially on efforts to prevent early marriage in order to reduce the level of violence against women committed by the Gorontalo District Women's Empowerment Office.

Data sources used in the preparation of this study consisted of primary data and secondary data. Primary data is data obtained directly from the original source in the form of interviews or opinions from individuals as well as observations of an object. Secondary data is a source of research data obtained through intermediary media or indirectly in the form of books, notes, evidence that already exists. Data collection is done through observation, documentation and interviews. 


\section{RESULTS AND DISCUSSION}

Indonesian marriage law number 1 of 1974 states that a woman's minimum age for marriage is 16 years. Adolescents who carry out marriages under the age of 20 In general do not have enough views and knowledge about how the role of a mother and a wife should be or the role of a man as father and head of the household. According to the National Population and Family Planning Agency (BKKBN), early marriage for women is likely to give birth to children who are low weight and have a short body and are at risk of developing heart and blood vessel disease (BKKBN, 2012. Book. Early Marriage in Several Provinces in Indonesia: Root of the Problem and Institutional Role in the Regions).

The percentage of marriages in Gorontalo Regency is explained in the table below. Men who were married in Gorontalo District from 2015 to 2018 can be seen in Table 1.

Table 1. Men married in Gorontalo district in 2015-2018

\begin{tabular}{ccccc}
\hline Age & Year 2015 & Year 2016 & Year 2017 & Year 2018 \\
\hline$<18$ years old & 85 & 15 & 15 & 12 \\
\hline $\begin{array}{c}18-21 \text { years } \\
\text { old }\end{array}$ & 432 & 897 & 893 & 376 \\
\hline $\begin{array}{c}22-25 \text { years } \\
\text { old }\end{array}$ & 681 & 957 & 957 & 619 \\
\hline $\begin{array}{c}26-30 \text { years } \\
\text { old }\end{array}$ & 613 & 827 & 827 & 311 \\
\hline $\begin{array}{c}31-35 \text { years } \\
\text { old }\end{array}$ & 308 & 411 & 411 & 98 \\
\hline 36 years old & 332 & 30 & 30 & \\
\hline
\end{tabular}

Source: Processed Primary Data 2019

Women who were married in Gorontalo District from 2015 to 2018 can be seen in Table 2.

Table 2. Married Women in 2015-2018

\begin{tabular}{ccccc}
\hline Age & Year 2015 & Year 2016 & Year 2017 & Year 2018 \\
\hline$<18$ years old & 419 & 10 & 10 & 98 \\
\hline $\begin{array}{c}18-21 \text { years } \\
\text { old }\end{array}$ & 661 & 1020 & 1020 & 486 \\
\hline $\begin{array}{c}22-25 \text { years } \\
\text { old }\end{array}$ & 695 & 1000 & 1000 & 521 \\
\hline $\begin{array}{c}26-30 \text { years } \\
\text { old }\end{array}$ & 480 & 751 & 751 & 261 \\
\hline $\begin{array}{c}31-35 \text { years } \\
\text { old }\end{array}$ & 216 & 259 & 259 & 119 \\
\hline 36 years old & 238 & 26 & 26 & 102 \\
\hline & Source: Processed Primary Data 2019 &
\end{tabular}

Based on the results of interviews in the data collection of marriage in the Gorontalo District Ministry of Religion that the difference in the number of female and male marriages in 2015-2018 was influenced by the majority of women married to men who came from outside Gorontalo District so that the women's 
data that took place during marriage 2015-2018 is more dominant than men who married in 2015-2018.

\section{A. Factors Causing Early Marriage}

Based on the results of interviews with respondents who married at an early age explained that the factors causing early marriage are:

\section{Promiscuity}

Promiscuity is one of the triggers for early marriage. Because usually promiscuity is usually done by teenagers who are entering a period of growth and curiosity about everything. The most promiscuity occurs in middle and high school adolescents, resulting in pregnancy out of wedlock.

According to the Head of Religion Affairs Office in West Limboto that adolescence is a period of our identity search. But at that time many teenagers who stepped wrong, due to hanging out of bounds that cause adverse effects on them such as pregnancy out of wedlock. All of that happened because of promiscuity and the world of the internet and cellphones which easily store pornographic films that made the children curious to imitate the scene. Pregnant out of wedlock is also due to lack of knowledge of the problems of sexology of adolescents doing without thinking about the risks that occur just to find out what it's like having sex due to watching pornographic films.

In anticipating these problems, instilling religious values, morals, ethics, and providing counseling focused on adolescents is the right thing to do. Based on this theory the researchers agree, this is in accordance with the data found in the field that to prevent the occurrence of promiscuity, the role of parents, society and teachers is needed to instill moral religious values, and ethics for adolescent women.

\section{Own will}

Early marriage caused by one's own will is in line with the theory put forward by Sarwono (2003), that early marriage occurs because subjects think emotionally to do marriage, the couple thinks of loving each other so that having relations outside of marriage causes pregnancy. The results of the interview explained that the reason for early marriage in most couples in Gorontalo was because of their own free will without coercion from the parents. Married at an early age because both men and women feel ready to get married.

\section{B. Forms of Domestic Violence}

Based on the results of interviews with the head of the field of Protection for Women and Children explained that there are several forms of domestic violence including abuse and neglect of the household.

\section{Physical abuse}

Physical violence is a type of violence that can be seen or visible. Where everyone can see because there is a physical clash between the perpetrators and victims of violence. For example slapping, slapping, tackling, stepping on feet, barking, spitting and throwing with things. Domestic violence is any act against a person especially a woman, which results in physical, sexual, psychological, and / or misery or neglect of the household, including threats to commit acts, coercion or deprivation of liberty unlawfully within the scope of the household. 
According to the Head of Women's and Children's Protection said that domestic abuse can be in the form of physical violence, which is violence that causes pain, falls ill and is seriously injured. Persecution usually occurs between married couples who often experience strife or even dissent in the household. Explanations regarding physical power in cases of domestic violence against women were obtained from several informants who were victims. Based on interviews with several victims that the abuse they had experienced was in the form of a slap, citing misunderstanding between them and their husbands. In addition, forms of abuse that have been reported were punched in the arms and pushed to hit the wall, mugged with knives, slapped and kicked.

\section{Abandonment}

Based on interviews with the Head of Protection for Women and Children stated that neglect of households is closely related to the economy. Namely in the form of not providing a living that should be borne by the husband for the survival of his wife or the restrictions or restrictions that cause economic dependence. For example, a husband forbids his wife from working to fulfill the family's daily needs, and does not provide spending money.

\section{Factors Causing Domestic Violence}

Factors causing domestic violence in this study, which is in accordance with the results of interviews with Iyam Dini, SKM, M.Kes as the head of protection for women and children said that the contributing factors are economic, alcohol, and infedility.

\section{Economy}

The most common cause of domestic violence is usually due to the low income of the husband who cannot meet the family's living needs. In addition to the low income other factors caused by the economy are household neglect. There are also households that have to be in debt because of the high necessities of household life that cannot balance their husband's income.

Based on interviews with several victims of domestic violence explained that the beginning of the fight was triggered by not meeting the primary needs of the family. From the fight, the husband finally violated his wife and children.

\section{Alcohol}

Alcohol is the most important factor in domestic violence. This is because when the husband consumes alcoholic beverages can make them do negative things, easy to be emotional, uncontrolled self-awareness that can trigger domestic violence.

Based on the results of interviews with several victims of violence that the factors causing the violence they experienced was when the husband was drunk. As a result the husband is always angry for no apparent reason and always damage the items in the house such as slamming a chair, breaking a glass, a plate and also likes to expel his wife from home.

\section{Infidelity}

In this case, the affair is committed by the husband with another woman or the husband marries and has another wife. This affair is also one of the factors a person commits domestic violence. Disharmony in the household is caused by the husband having an affair with another woman. No wonder a third person is also one of the triggers for domestic violence. Based on interviews with several 
victims of violence that the violence they experienced was beaten, slapped and often snapped by their husbands because they had an affair that made them more sensitive so that it was easy to abuse the wife.

\section{Efforts Made by the Office of Women's Empowerment}

\section{A. Integrated service center for empowering women and children (P2TP2A)}

Service centers that provide services for the community focused on women for acts of violence. P2TP2A is also an operational vehicle for realizing women's empowerment through a variety of physical services, information, consultation referrals and skills upgrading and other activities. This service center is considered to provide benefits where women victims of violence can easily carry out consultations on household problems they experience.

\section{B. The Task Force Team against acts of violence against women and children (PPA Task Force)}

The tasks and functions of the PPA Task Force are broken down into 3 namely prevention of the problem of protecting women and children, services and assistance of women and children who experience violence and reporting data and information about cases that occur in their working area. With this women's and child violence task force team they can find out and easily report any problems they experience in the household.

\section{Socialization}

The socialization carried out by the P2TPA service is socialization among the community about handling violence against women so that they can show concern for the local government. With this socialization it is hoped that it can increase women's awareness that the violence they have been experiencing is one of the consequences of their early marriage.

\section{Assistance}

Social relations between the assistant and the victim in the form of providing facilities to solve problems. In P2TP2A Kabupaten Gorontalo the victims who reported the most were wives with the most frequent cases accompanied by P2TP2A officers being domestic violence. For victims who report to officers, shelter or temporary houses are usually provided for victims to stay overnight while the case is being handled. Thus the victim will feel protected.

Victims of domestic violence are given psychological guidance as an effort to recover traumatic victims within a certain period. Individual behavior, both victims and perpetrators are strongly influenced by socio-cultural, economic and political factors in which values, norms and laws that apply in society and the state influence in seeing the issue of violence against women.

\section{E. Puspaga Mobile}

Puspaga mobile is a superior program carried out by P2TPA to overcome the problem of violence against women and children. Puspaga is a place of learning aimed at improving the quality of life towards a prosperous family carried out by professionals such as counselors, both psychologists or professional psychology scholars. Puspaga Mobile has carried out activities in the form of direct assistance and provide solutions in accordance with the problems encountered without entering the realm of law. 


\section{CLOSING}

Based on the results of the study it can be concluded that early marriage is one of the factors causing the high level of domestic violence in Gorontalo District. As for the factors that triggered the occurrence of early marriage, namely promiscuity and socioeconomic conditions in society. The efforts made by Gorontalo District Government through the Office of Women's Empowerment and Child Protection to prevent early marriage in reducing the level of violence in women namely: opening an integrated service center for empowering women and children; forming a task force team for violence against women and children; provide integrated community-based protection; conduct outreach and assistance; and the Puspaga Mobile program. In addition, in order to support the government program, active participation from all elements of the community is certainly needed. The creation of a good social environment through religious and cultural approaches as well as economic stability will help reduce the level of early marriage and domestic violence.

\section{BIBLIOGRAPHY}

Amelia Rizqy, Mohdari dan Aulia Azizah. 2017. Pengaruh Penyuluhan Terhadap Pengetahuan Remaja Tentang Pernikahan Dini Di Kelas Viii Di Smp Negeri 4 Banjarmasin. Jurnal. Dinamika Kesehatan. Vol. 8 No.3

Alfiyah. 2010. Sebab-sebab Pernikahan Dini. Jakarta. EGC

BPS.2016. Perkawinan usia anak di Indonesia. Jakarta ISBN.978-979-064-971-2

BKKBN Provinsi Gorontalo. Tren Fertilitas dan Keluarga Berencana Tahun 2006 - 2012, 2013, Fact Sheet.

BKKBN. 2012. Pernikahan Dini pada Beberapa Provinsi di Indonesia: Akar Masalah dan Peran Kelembagaan di Daerah. Jakarta: Direktorat Analisis Dampak Kependudukan BKKBN.

Febrianto Samuel. 2016. Kekerasan Anak dan Perempuan di Gorontalo Sangat Mengkhawatirkan.http://www.tribunnews.com/tribunners/2016/02/23/k ekerasan-anak-dan-perempuan-di-gorontalo-sangat-mengkhawatirkan. (Diakses 14 Desember 2018)

Harnoko.B. Rudi. 2010. Dibalik Tindak Kekerasan Terhadap Perempuan. Muwazah. http://e-journal.stainpekalongan.ac.id/ (Diakses 14 Desember 2018)

Hertika Putri Mareta, Lantin Sulistyorini dan Emi Wuri Wuryaningsih. 2017. Hubungan Pernikahan Usia Dini dengan Risiko Tindak Kekerasan oleh Ibu pada Anak Usia Prasekolah di Kelurahan Sumbersari Kecamatan Sumbersari Kabupaten Jember. e-Jurnal Pustaka Kesehatan. vol.5 No. 3

Hendrarti dan Herudjati Purwoko, Aneka Sifat Kekerasan Fisik, Simbolik, Birokratik \& Struktural, Cetakan Pertama, PT Indeks, Jakarta, 2008, hal vi.

Kumalasari, F. dan Ahyani, L.N. (2012). "Hubungan Antara Dukungan Sosial Dengan Penyesuaian Diri Remaja di Panti Asuhan". Jurnal Psikologi Tutur. Volume 1, No. 1, Hal. 21-31.

Mariyatul Qibtiyah. 2014 Faktor yang Mempengaruhi Perkawinan Muda Perempuan. Jurnal Biometrika dan Kependudukan.Vol. 3, No. 1 50-58

Malhotra. A.Warner. A. McGonagle. A. 2011. Solutions to end child marriage: what the evidence shows. Washington. DC: ICRW.Mubasyaroh. 2016. Analisis Faktor Penyebab Pernikahan Dini Dan Dampaknya Bagi 
Pelakunya. Jurnal Pemikiran dan Penelitian Sosial Keagamaan. Yudisia, Vol. 7, No. 2

Musfiroh. Mayadina Rohmi. 2016. Pernikahan Dini dan Upaya Perlindungan Anak di Indonesia. Jurnal Hukum dan Syariah. Vol. 8, No. 2, hal. 64-73 Print ISSN: 2085-1618, Online ISSN: 2528-1658

Muchsin,Varia Peradilan no. 303, IKAHI, Jakarta, 2011, hal. 18.

Reni Kartikawati. 2014. Dampak Perkawinan Anak di Indonesia. Jurnal Studi Pemuda. Vol. 3, No. 1.

Samadani Adil. 2013. Kompetensi Pengadilan Agama Terhadap Tindak Kekerasan Dalam Rumah Tangga. Yogyakarta: Graha Ilmu

Sumbulah Umi Dan Faridatul Jannah. 2012. Pernikahan Dini Dan Implikasinya Terhadap Kehidupan Keluarga Pada Masyarakat Madura (Perspektif Hukum Dan Gender). Jurnal Kesetaraan dan Keadilan Gender, Volume VII No. 1 hlm. 83-101

Soeroso Moerti Hadiati. 2010. Kekerasan Dalam Rumah Tangga Dalam Perspektif. Yuridis-Viktimologis. Jakarta : Sinar Grafika.

Young, eoin \& lisa Quinn. (2002). Writing effective public policy papers. Hungary: Local Government and Public Service Reform Initiative, Open ASociety Institute Budapest. 